\title{
Sensory Evaluation and Proximate Composition of Rice Based Traditional Food Products of India
}

\author{
A. Lavanya* and Boora Pinky \\ Department of Foods and Nutrition, CCS Haryana Agricultural University, \\ Hisar, 125004, Haryana., India \\ *Corresponding author
}

\section{A B S T R A C T}

\section{Keywords}

Sensory evaluation,

Nutritional

composition,

Traditional food,

Rice varieties

Article Info

Accepted:

15 May 2019

Available Online:

10 June 2019
The present study was undertaken with the view to evaluate the sensory attributes and proximate composition of rice based traditional food products like dosa, idli, utthapam, khichadi and rice biryani were prepared using different varieties of rice. The four different rice varieties namely permal (control), HB-2, HKR-48 and HKR-128 were selected for the study. The best acceptable variety (HKR-48) with best acceptable food products were selected organoleptically and evaluated for proximate composition. Highly significant $(\mathrm{P}<0.05)$ differences for crude protein content and crude fibre content were observed in food products prepared from HKR-48 variety while non-significant differences were observed for crude fat and ash content. Nutritional evaluation of rice based food products revealed that this product contains good amount of protein, carbohydrates and minerals. All the food products from HKR-48 rice variety were organoleptically acceptable as compared to other varieties.

\section{Introduction}

Traditional Indian foods have been prepared for many years and preparation varies across the country. Khichadi made from rice together with dal is highly nutritious. Traditional wisdom about processing of food, its preservation techniques, and their therapeutic effects has been established for many generations in India. Indian traditional foods are also recognized as functional foods because of the presence of functional components such as body-healing chemicals, antioxidants, dietary fibers and probiotics. These functional molecules help in weight management, blood sugar level balance and support immunity of the body. The functional properties of foods are further enhanced by processing techniques such as sprouting, malting and fermentation (Hotz and Gibson, 2007).

Fermented cereals have been noted for their superior nutritional value, shelf-life and digestibility compared to the unfermented counterpart (Coda et al., 2011). Use of rice along with pulses (black gram, bengal gram) is necessary as a source of mixed natural microflora needed for efficient fermentation during preparation of idli, dosa, dhokla 
batters. A group of microbes (natural or from starter culture) grow well in cereal based foods, biochemically and organoleptically transform the substrates, produce different metabolites, destroys or detoxifies the harmful products (phytates, tannins, and polyphenols) and enrich the food with different micro-nutrients (vitamins, minerals, amino acids, etc.), health beneficial edible microbes (i.e. probiotics), fermentable sugars (i.e. prebiotic), dietary fibers, phytochemicals and digestive enzymes.

Apart from basic nutrients, bioactive component exhibits significant beneficial effects on the intestinal micro environment, particularly modulating gut microbial composition and their functional behavior. Keeping this fact in view, the present study has been planned with objectives to utilize the newly released rice varieties to develop Indian rice based traditional food products and also to evaluate their sensory and nutritional composition.

\section{Materials and Methods}

\section{Procurement and preparation of samples}

Rice varieties namely HB-2, HKR-48, HKR128 and Permal were procured in a single lot from Rice Research Station, Kaul (District Kaithal), CCS Haryana Agricultural University, Hisar after milling by using HULLER-MILLER JAPAN equipment. All the four rice varieties utilized for development of food products like Dosa, Idli, Utthapam, Khichadi and Rice biryani. The Permal locally grown common rice variety served as a control. The grain of the four rice varieties were cleaned and made free of dust, dirt and foreign materials prior to development of food products. All other food ingredients required for development of food products were purchased from local market in a single lot.

\section{Preparation of food products}

Batter preparation for Dosa, Idli and Utthapam

\section{Ingredients - Quantity}

Rice - $1 \mathrm{~kg}$

Black gram - $500 \mathrm{~g}$

Fenugreek seeds - 1 tsp

Water - 1 litre

Salt - 3 tsp

\section{Method}

The rice and blackgram dhal were soaked in one litre of water separately for 6 hours. Soaked ingredients were transferred in a mixer-grinder for grinding. Ground rice and black gram paste were mixed together. The ground mixture was kept for fermentation in incubator at temperature $20^{\circ} \mathrm{C}$ for overnight. The mixture was used in different consistency and viscosity according to the products.

\section{Preparation of food products}

\section{Dosa}

\section{Ingredients - Quantity}

Dosa batter - $150 \mathrm{ml}$

Oil - $5 \mathrm{ml}$

\section{Method}

Dosa is a crispy savoury pancake/crepe of South Indian cuisine. It is prepared by grinding rice and black gram dhal in a fixed proportion (2:1) fermented and then preparation on a flat Dosa pan.

Initially the oil was spread on the non-stick Dosa pan. The Dosa batter was spread on the pan finely to get the thin and crispy texture. Cooked for 3 minutes 
Idli

\section{Ingredients - Quantity}

Idli batter - $150 \mathrm{ml}$

\section{Method}

Idli batter was placed on the plates in the idli cooker. Cooked upto the whistles.

\section{Utthapam}

Ingredients - Quantity

Thick batter $-150 \mathrm{ml}$

Oil - $5 \mathrm{ml}$

\section{Method}

Uthappam is a dosa-like dish made by cooking the fermented batter of rice and black gram dal on a pan. Unlike a Dosa, which is crisp and crepe-like, Uttapam is a thick pancake, with toppings cooked right into the batter. Initially the oil was spread on the nonstick dosa pan. The batter was spread on the pan to get thick Utthapam. Cooked for 4 minutes

\section{Khichadi}

\section{Ingredients - Quantity}

Rice - $110 \mathrm{~g}$

Whole green gram dhal - 50g

Splitted decorticated, green gram dhal - 20g

Spinach leaves - $20 \mathrm{~g}$

Turmeric powder $-1 / 2$ tsp

Water (water and rice 3:1 ratio) - 330ml

\section{Method}

The Khichadi is most common food and split decorticated Moong dal and rice is the popular combination of Khichadi. All the above mentioned ingredients were pressure cooked for 20 minutes in pressure cooker.

\section{Rice biryani}

\section{Ingredients - Quantity}

Rice - $200 \mathrm{~g}$

Cauliflower, peas, carrots, beans - $300 \mathrm{~g}$

Onion and tomato - $200 \mathrm{~g}$

Green chilli - $50 \mathrm{~g}$

Ginger garlic paste (ginger and garlic1:1 ratio) - $100 \mathrm{~g}$

Corriander and mint leaves - $40 \mathrm{~g}$

Clove and dalchinni - $4 \mathrm{~g}$

Curd - 2 tsp

Oil - $50 \mathrm{ml}$

Salt - required amount

Water (water and rice 2:1 ratio) - $400 \mathrm{ml}$

\section{Method}

Vegetable Biryani is an Indian dish made with highly seasoned rice and vegetables flavored with turmeric. Initially oil was added in a cooker. Dalchinni, clove, pudina, green chilli, onion, tomato and ginger garlic paste were fried in oil. All the vegetables were added (cauliflower, peas, carrot, beans) and mixed properly. Required amount of water was added and allowed for boiling. Rice was added into the boiling mixture and pressure cooked for 15 minutes.

\section{Sensory evaluation}

All the food products were subjected to sensory evaluation with respect to colour, appearance, aroma, texture, taste and overall acceptability by a semi-trained taste panel comprising of 10 judges using the 9 point Hedonic Rating scale. On the basis of mean scores of sensory evaluation obtained after feeding to the judges, the most acceptable products were selected for further nutritional studies. 


\section{Proximate composition}

The proximate analysis of prepared samples was done in triplicates.

The proximate composition of rice samples were determined by employing the standard methods of analysis AOAC, (2000). The moisture content of the rice samples was determined after drying at $65^{\circ} \mathrm{C}$ until a constant weight was attained. The micro Kjeldahl method was employed to determine the total nitrogen and the crude protein $(\mathrm{N} \mathrm{x}$ 5.95). The crude fat was extracted with petroleum ether, using Socsplus - SCS.08 RTS apparatus. The ash and crude fibre contents were determined based on methods outlined in AOAC (2000).

\section{Statistical Analysis}

The data for sensory evaluation, nutritional composition and in-vitro digestibility of food products were statistically analyzed for analysis of variance (ANOVA) at 95\% probability to find out significant differences between control (permal) and accepted (HKR48) rice varieties. Analysis was performed using completely randomized design (CRD) with three replications and variable treatments by OPSTAT software (Panse and Sukhatme, 1961).

\section{Results and Discussion}

\section{Sensory evaluation}

All the four rice varieties Permal, HB-2, HKR-48 and HKR-128 were used for the preparation of food products and subjected to sensory evaluation with respect to colour, appearance, aroma, texture, taste and overall acceptability.

The data in table 1 indicated that Dosa prepared from four different rice varieties namely control Dosa, HB-2 Dosa, HKR-48 and HKR-128 Dosa were fall in the category of "liked moderately" in overall acceptability whereas the aroma of control Dosa was "liked very much" and taste of HKR-128 Dosa was "liked slightly:" by panel of experts. Mean organoleptic scores for Idli showed in table 2 revealed that control Idli, HB-2 Idli and HKR-48 Idli were "liked moderately" in terms of all the sensory attributes. Idli prepared from HKR-128 rice variety was liked slightly in overall acceptability. The colour and appearance of control Idli was "liked very much" by the judges.

The mean scores depicted in table 3 showed the results of Utthapam prepared from Permal, HB-2 and HKR-48 falls in the category of "liked moderately" for all sensory attributes whereas Utthapam prepared from HKR-128 variety was "liked slightly" by the judges. The colour and appearance of control Utthapam was "liked very much" by the panel of experts.

The table 4 showed that the Khichadi prepared from four different rice varieties were fall in the category of "liked moderately" by judges. The appearance of control Khichadi was "liked very much" by panel of experts.

The data in table 5 depicted that Rice Biryani prepared from HKR-48 was "liked moderately" in overall acceptability. The colour of control Biryani was "liked very much" whereas all the other sensory attributes were "liked moderately" by the judges. The other three varieties of Biryani were also fall in the category of liked moderately in all the sensory attributes by the panel of experts. Overall results of sensory evaluation of food products prepared from different rice varieties revealed that HKR-48 was best acceptable rice variety for the preparation of rice based traditional food products of India. 
Table.1 Sensory evaluation of Dosa prepared from different rice varieties

\begin{tabular}{|l|c|c|c|c|c|c|}
\hline Variety & Colour & Appearance & Aroma & Texture & Taste & $\begin{array}{l}\text { Overall } \\
\text { Acceptability }\end{array}$ \\
\hline $\begin{array}{l}\text { Control } \\
\text { Dos } \boldsymbol{a}\end{array}$ & $7.70 \pm 0.42$ & $7.90 \pm 0.31$ & $8.20 \pm 0.33$ & $7.90 \pm 0.35$ & $7.60 \pm 0.34$ & $\mathbf{7 . 8 6} \pm \mathbf{0 . 3 1}$ \\
\hline $\begin{array}{l}\text { HB-2 } \\
\text { Dos } \boldsymbol{a}\end{array}$ & $7.40 \pm 0.27$ & $7.50 \pm 0.22$ & $7.50 \pm 0.31$ & $7.20 \pm 0.25$ & $7.20 \pm 0.33$ & $\mathbf{7 . 3 6 \pm 0 . 2 2}$ \\
\hline $\begin{array}{l}\text { HKR-48 } \\
\text { Dosa }\end{array}$ & $7.50 \pm 0.22$ & $7.40 \pm 0.27$ & $7.20 \pm 0.13$ & $7.40 \pm 0.34$ & $7.60 \pm 0.37$ & $\mathbf{7 . 4 2} \pm \mathbf{0 . 2 2}$ \\
\hline $\begin{array}{l}\text { HKR-128 } \\
\text { Dosa }\end{array}$ & $7.10 \pm 0.23$ & $7.10 \pm 0.18$ & $7.30 \pm 0.21$ & $7.00 \pm 0.15$ & $6.90 \pm 0.18$ & $\mathbf{7 . 0 8} \pm \mathbf{0 . 1 1}$ \\
\hline CD(P<0.05) & $\mathbf{0 . 8 5}$ & $\mathbf{0 . 7 2}$ & $\mathbf{0 . 7 2}$ & $\mathbf{0 . 8 1}$ & $\mathbf{0 . 8 9}$ & $\mathbf{0 . 6 4}$ \\
\hline
\end{tabular}

Values are mean \pm SE of three independent determinations

Table.2 Sensory evaluation of Idli prepared from different rice varieties

\begin{tabular}{|l|c|c|c|c|c|c|}
\hline Variety & Colour & Appearance & Aroma & Texture & Taste & $\begin{array}{l}\text { Overall } \\
\text { Acceptability }\end{array}$ \\
\hline $\begin{array}{l}\text { Control } \\
\text { Idli }\end{array}$ & $8.10 \pm 0.18$ & $8.10 \pm 0.18$ & $7.60 \pm 0.22$ & $7.10 \pm 0.31$ & $7.50 \pm 0.22$ & $\mathbf{7 . 6 8} \pm \mathbf{0 . 1 6}$ \\
\hline $\begin{array}{l}\text { HB-2 } \\
\text { Idli }\end{array}$ & $7.20 \pm 0.25$ & $7.50 \pm 0.31$ & $7.10 \pm 0.31$ & $7.10 \pm 0.31$ & $7.30 \pm 0.37$ & $\mathbf{7 . 2 7} \pm \mathbf{0 . 2 7}$ \\
\hline $\begin{array}{l}\text { HKR-48 } \\
\text { Idli }\end{array}$ & $7.60 \pm 0.16$ & $7.60 \pm 0.16$ & $7.20 \pm 0.29$ & $7.10 \pm 0.31$ & $7.20 \pm 0.33$ & $\mathbf{7 . 3 4 \pm 0 . 2 3}$ \\
\hline $\begin{array}{l}\text { HKR-128 } \\
\text { Idli }\end{array}$ & $6.80 \pm 0.25$ & $6.80 \pm 0.25$ & $6.70 \pm 0.26$ & $6.30 \pm 0.33$ & $6.50 \pm 0.43$ & $\mathbf{6 . 6 2 \pm 0 . 2 6}$ \\
\hline CD(P $\leq \mathbf{0 . 0 5})$ & $\mathbf{0 . 6 1}$ & $\mathbf{0 . 6 6}$ & $\mathbf{0 . 7 8}$ & $\mathbf{0 . 9 1}$ & $\mathbf{0 . 9 8}$ & $\mathbf{0 . 6 7}$ \\
\hline
\end{tabular}

Values are mean \pm SE of three independent determinations

Table.3 Sensory evaluation of Utthapam prepared from different rice varieties

\begin{tabular}{|l|c|c|c|c|c|c|}
\hline Variety & Colour & Appearance & Aroma & Texture & Taste & $\begin{array}{l}\text { Overall } \\
\text { Acceptability }\end{array}$ \\
\hline $\begin{array}{l}\text { Control } \\
\text { Utthappam }\end{array}$ & $8.10 \pm 0.18$ & $8.10 \pm 0.18$ & $7.60 \pm 0.22$ & $7.10 \pm 0.31$ & $7.50 \pm 0.22$ & $\mathbf{7 . 6 8} \pm \mathbf{0 . 1 6}$ \\
\hline $\begin{array}{l}\text { HB-2 } \\
\text { Utthappam }\end{array}$ & $7.20 \pm 0.25$ & $7.50 \pm 0.31$ & $7.10 \pm 0.31$ & $7.10 \pm 0.31$ & $7.30 \pm 0.37$ & $\mathbf{7 . 2 7} \pm \mathbf{0 . 2 7}$ \\
\hline $\begin{array}{l}\text { HKR-48 } \\
\text { Uthappam }\end{array}$ & $7.60 \pm 0.16$ & $7.60 \pm 0.16$ & $7.20 \pm 0.29$ & $7.10 \pm 0.31$ & $7.20 \pm 0.33$ & $\mathbf{7 . 3 4 \pm 0 . 2 3}$ \\
\hline $\begin{array}{l}\text { HKR-128 } \\
\text { Utthappam }\end{array}$ & $6.80 \pm 0.25$ & $6.80 \pm 0.25$ & $6.70 \pm 0.26$ & $6.30 \pm 0.33$ & $6.50 \pm 0.43$ & $\mathbf{6 . 6 2 \pm 0 . 2 6}$ \\
\hline CD(P $\leq \mathbf{0 . 0 5})$ & $\mathbf{0 . 6 1}$ & $\mathbf{0 . 6 6}$ & $\mathbf{0 . 7 8}$ & $\mathbf{0 . 9 1}$ & $\mathbf{0 . 9 8}$ & $\mathbf{0 . 6 7}$ \\
\hline
\end{tabular}

Values are mean \pm SE of three independent determinations 
Table.4 Sensory evaluation of Khichadi prepared from different rice varieties

\begin{tabular}{|l|c|c|c|c|c|c|}
\hline Variety & Colour & Appearance & Aroma & Texture & Taste & Overall acceptability \\
\hline Control Khichadi & $7.80 \pm 0.25$ & $8.00 \pm 0.21$ & $7.40 \pm 0.22$ & $7.70 \pm 0.37$ & $7.60 \pm 0.27$ & $\mathbf{7 . 7 0 \pm 0 . 2 2}$ \\
\hline HB-2 Khichadi & $7.50 \pm 0.22$ & $7.10 \pm 0.18$ & $7.40 \pm 0.22$ & $7.40 \pm 0.22$ & $7.40 \pm 0.22$ & $\mathbf{7 . 3 6} \pm \mathbf{0 . 1 4}$ \\
\hline HKR-48 Khichadi & $7.70 \pm 0.26$ & $7.70 \pm 0.30$ & $7.50 \pm 0.22$ & $7.30 \pm 0.15$ & $7.30 \pm 0.21$ & $7.50 \pm 0.20$ \\
\hline HKR-128 Khichadi & $7.60 \pm 0.22$ & $7.30 \pm 0.21$ & $7.40 \pm 0.22$ & $7.20 \pm 0.29$ & $7.50 \pm 0.27$ & $\mathbf{7 . 4 0 \pm 0 . 1 6}$ \\
\hline CD(P $\leq \mathbf{0 . 0 5})$ & $\mathbf{0 . 6 8}$ & $\mathbf{0 . 6 6}$ & $\mathbf{0 . 6 3}$ & $\mathbf{0 . 7 7}$ & $\mathbf{0 . 6 9}$ & $\mathbf{0 . 5 1}$ \\
\hline
\end{tabular}

Values are mean \pm SE of three independent determinations

Table.5 Sensory evaluation of Rice Biryani prepared from different rice varieties

\begin{tabular}{|l|c|l|c|c|c|c|}
\hline Variety & Colour & Appearance & Aroma & Texture & Taste & Overall Acceptability \\
\hline Control Biryani & $8.00 \pm 0.15$ & $7.80 \pm 0.25$ & $7.70 \pm 0.21$ & $7.50 \pm 0.27$ & $7.50 \pm 0.27$ & $\mathbf{7 . 7 0} \pm \mathbf{0 . 2 2}$ \\
\hline HB-2 Biryani & $7.30 \pm 0.21$ & $7.20 \pm 0.25$ & $7.40 \pm 0.37$ & $7.20 \pm 0.25$ & $7.20 \pm 0.29$ & $\mathbf{7 . 2 6} \pm \mathbf{0 . 2 5}$ \\
\hline HKR-48 Biryani & $7.30 \pm 0.26$ & $7.20 \pm 0.25$ & $7.50 \pm 0.17$ & $7.10 \pm 0.18$ & $7.30 \pm 0.30$ & $\mathbf{7 . 2 8} \pm \mathbf{0 . 1 9}$ \\
\hline HKR-128 Biryani & $7.20 \pm 0.20$ & $7.20 \pm 0.25$ & $7.10 \pm 0.23$ & $7.00 \pm 0.20$ & $7.20 \pm 0.20$ & $\mathbf{7 . 1 4} \pm \mathbf{0 . 1 8}$ \\
\hline CD(P $\leq \mathbf{0 . 0 5})$ & $\mathbf{0 . 6 0}$ & $\mathbf{0 . 6 8}$ & $\mathbf{0 . 7 3}$ & $\mathbf{0 . 6 9}$ & $\mathbf{0 . 7 6}$ & $\mathbf{0 . 6 0}$ \\
\hline
\end{tabular}

Values are mean \pm SE of three independent determinations

Table.6 Proximate composition of food products from rice varieties (g/100g, on dry weight basis)

\begin{tabular}{|c|c|c|c|c|c|}
\hline Products & ${ }^{\circ}$ Moisture & Crude protein & Crude fat & Ash & Crude fibre \\
\hline \multicolumn{6}{|l|}{ DOSA } \\
\hline Control Dosa & $35.52 \pm 0.15$ & $3.44 \pm 0.03$ & $2.48 \pm 0.25$ & $2.12 \pm 0.37$ & $0.21 \pm 0.01$ \\
\hline HKR-48 Dosa & $35.19 \pm 0.07$ & $3.45 \pm 0.01$ & $3.74 \pm 0.55$ & $2.66 \pm 0.16$ & $0.63 \pm 0.12$ \\
\hline [tcal] & NS & NS & NS & NS & NS \\
\hline \multicolumn{6}{|l|}{ IDLI } \\
\hline HKR-48 Idli & $73.22 \pm 0.47$ & $3.78 \pm 0.06$ & $0.43 \pm 0.10$ & $1.52 \pm 0.17$ & $0.48 \pm 0.01$ \\
\hline [tcal] & NS & NS & NS & NS & $\mathbf{7 . 4 6} \square \square$ \\
\hline \multicolumn{6}{|l|}{ UTTHAPAM } \\
\hline Control Utthapam & $36.52 \pm 0.17$ & $3.84 \pm 0.07$ & $3.71 \pm 0.05$ & $4.95 \pm 0.87$ & $0.45 \pm 0.03$ \\
\hline HKR-48 Utthapam & $36.08 \pm 0.02$ & $4.49 \pm 0.9$ & $3.41 \pm 0.68$ & $3.66 \pm 0.08$ & $0.57 \pm 0.08$ \\
\hline [tcal] & $4.04 \square$ & 6.13 $\square \square$ & NS & 9.47 $\square \square$ & NS \\
\hline \multicolumn{6}{|l|}{ BIRYANI } \\
\hline Control Biryani & $69.27 \pm 0.02$ & $13.58 \pm 0.09$ & $14.88 \pm 0.30$ & $3.51 \pm 0.37$ & $1.60 \pm 0.01$ \\
\hline HKR-48 Biryani & $69.06 \pm 0.02$ & $15.83 \pm 0.31$ & $13.66 \pm 0.41$ & $3.71 \pm 0.37$ & $1.86 \pm 0.01$ \\
\hline [tcal] & $6.15 \square$ & $5.30 \square$ & NS & NS & $22.63 \square \square$ \\
\hline
\end{tabular}

Note: Values are mean $\pm \mathrm{SE}$ of three independent determinations

*Significant difference at $5 \%$ level

**Significant difference at $1 \%$ level NS- Non significant

- Moisture content on fresh weight basis $(\mathrm{g} / 100 \mathrm{~g})$ 


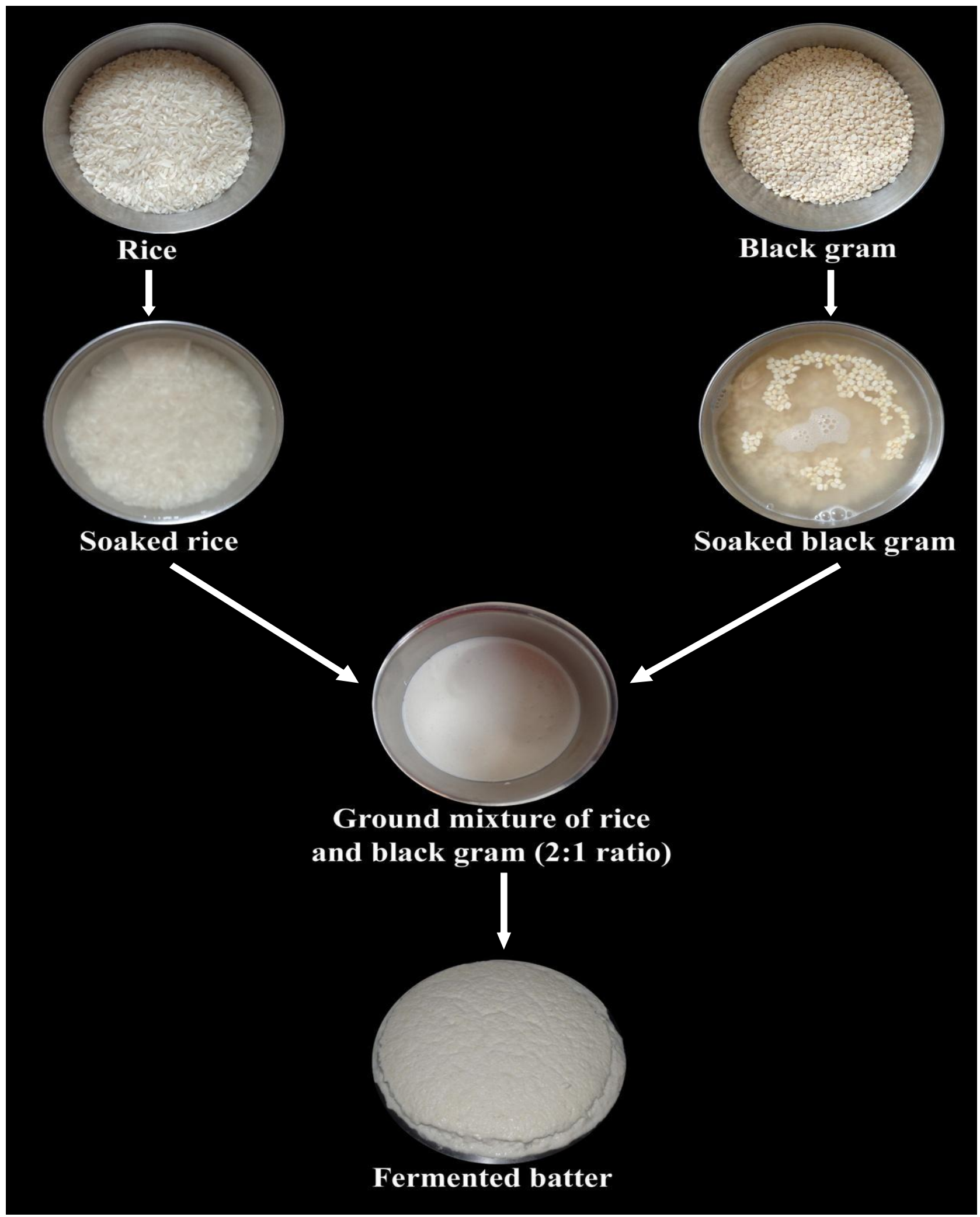



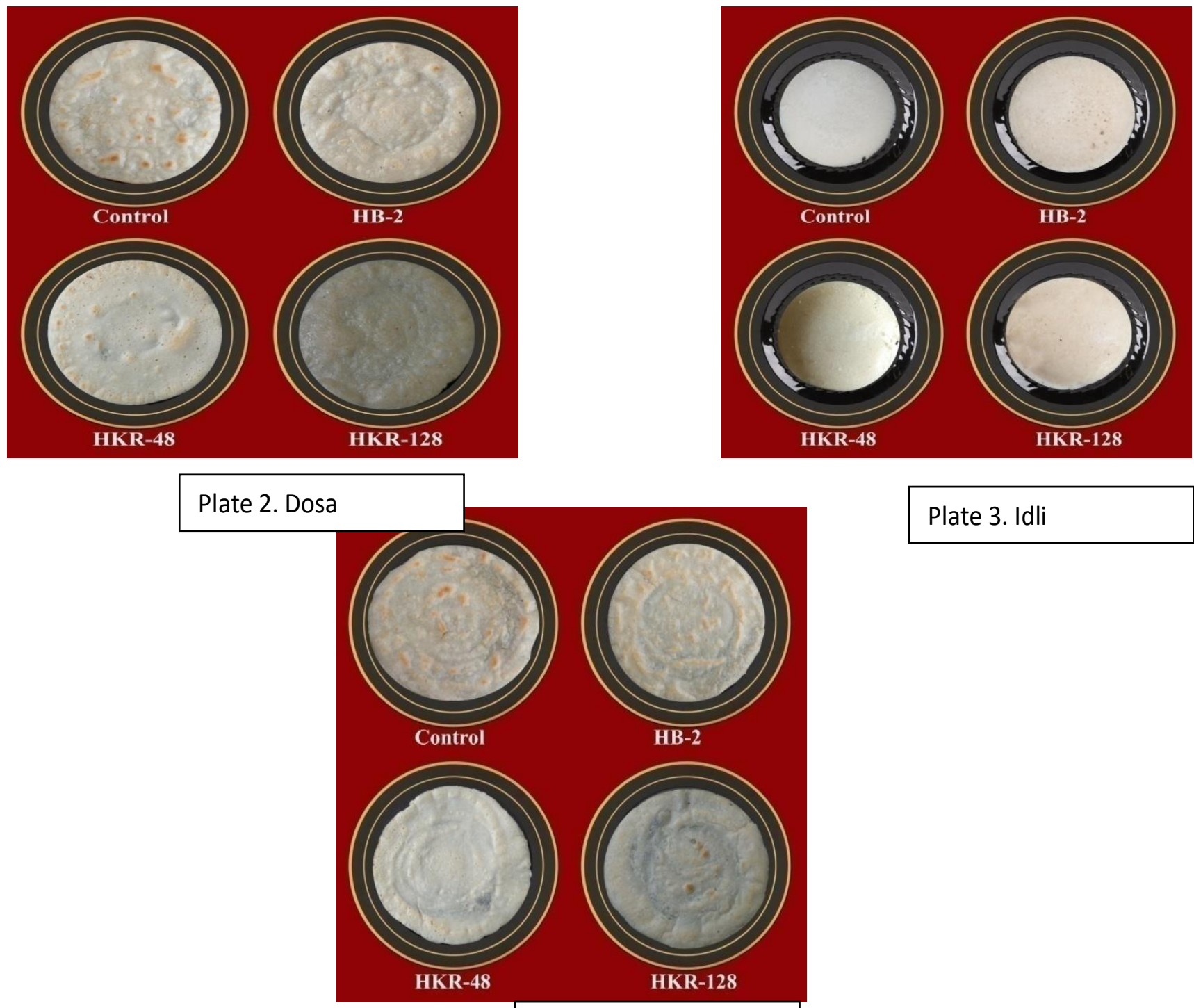

Plate 4. Utthapam
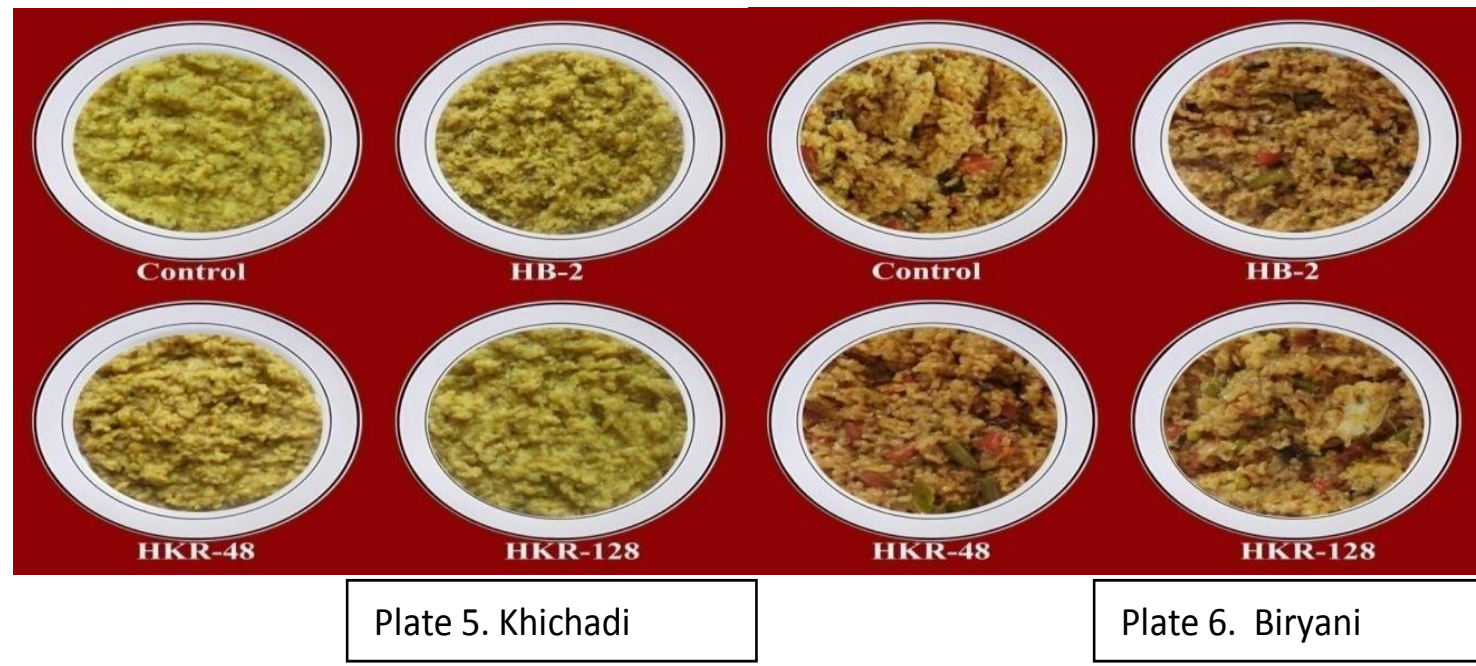

Plate 6. Biryani 


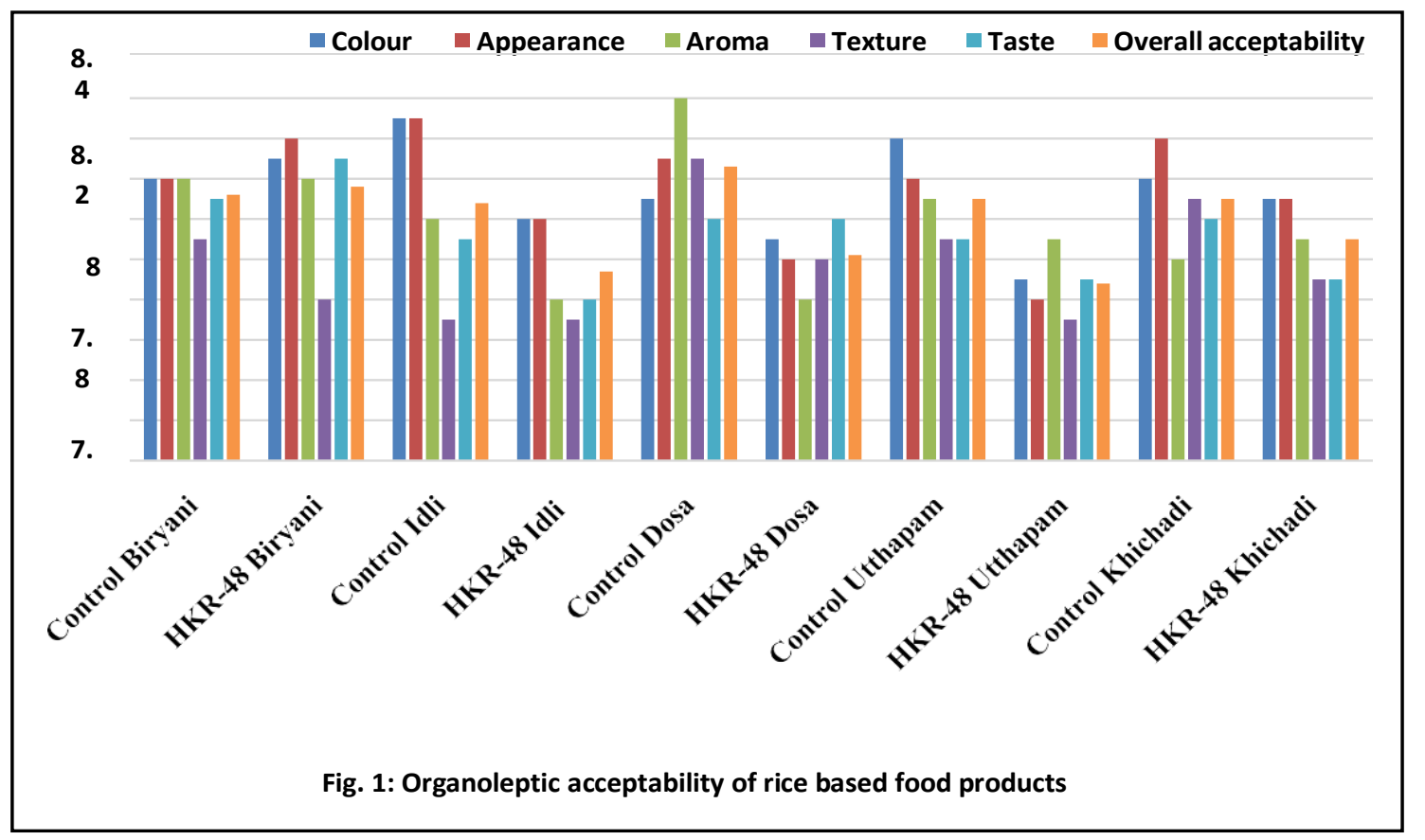

The figure 1 shows the comparison of sensory evaluation of food products prepared from permal (control variety) and HKR-48 rice variety. The organoleptic evaluation of various food products namely dosa, idli, utthapam, khichadi and rice biryani from control rice variety (Permal) and HKR-48 variety were liked moderately. A nonsignificant difference were observed in terms of overall acceptability of food products prepared from both varieties by panel of judges whereas the control counterparts of dosa (aroma), idli (colour and appearance), utthapam (colour), khichadi (appearance) were "liked very much". Significant $(\mathrm{P}<0.05)$ differences were observed in aroma of control and HKR-48 dosa $(\mathrm{P}<0.01)$, colour and appearance of control and HKR-48 idli, and in colour of control and HKR-48 utthapam $(\mathrm{P}<0.05)$.

\section{Nutritional composition}

\section{Proximate composition}

The results of proximate composition are furnished in table 6 .

\section{Moisture}

The moisture content of HKR-48 khichadi $(80.02 \mathrm{~g} / 100 \mathrm{~g})$ and biryani $(69.06 \mathrm{~g} / 100 \mathrm{~g})$ was significantly $(\mathrm{P}<0.05)$ lower as compared to their control.

A non-significant difference in moisture content was observed between dosa, idli and utthapam prepared from control and HKR-48 rice varieties. The findings of the present study are comparable with those reported earlier in dosa and utthapam by Amreen (2008) and Beniwal and Jood (2015). The results of Idli are in line with those reported earlier by Teniola and Odunfa, (2001); Blandino et al., (2003) and Moktan et al., (2011).

A non-significant difference was observed in the moisture content of both control and HKR-48 utthapam. The moisture content of control utthapam and HKR-48 utthapam were 36.52 and $36.08 \mathrm{~g} / 100 \mathrm{~g}$, respectively. The findings of utthapam are in line for moisture content of utthapam reported earlier by Amreen (2008). 


\section{Crude protein}

The crude protein content of control dosa was $3.44 \mathrm{~g} / 100 \mathrm{~g}$. The crude protein content of HKR-48 dosa was $3.45 \mathrm{~g} / 100 \mathrm{~g}$. A nonsignificant difference was observed in crude protein content of both dosa. The results obtained from the present investigation are lesser than range reported for protein in dosa and utthapam earlier by krishnamoorthy et al., 2013, Amreen (2008) and Beniwal and Jood (2015). The crude protein content of control idli was $3.56 \mathrm{~g} / 100 \mathrm{~g}$. The crude protein content of HKR-48 biryani was 3.78 $\mathrm{g} / 100 \mathrm{~g}$. A non-significant difference was observed in crude protein content of both idli. The findings of the present study are in line with those reported earlier by Teniola and Odunfa, (2001); Blandino et al., (2003) and Moktan et al., (2011).

The crude protein content of control utthapam was $3.84 \mathrm{~g} / 100 \mathrm{~g}$. The crude protein content of HKR-48 utthapam was $4.49 \mathrm{~g} / 100 \mathrm{~g}$. A significant difference was observed in crude protein content of both utthapam. The findings of the present study are closely agreement with results reported earlier by Ray and Swain (2013). The data revealed that the crude protein content of control khichadi was $5.22 \mathrm{~g} / 100 \mathrm{~g}$. The crude protein content of HKR-48 khichadi was $6.29 \mathrm{~g} / 100 \mathrm{~g}$.

A significant difference was observed in crude protein content of both khichadi. Rahangadale et al., (2014) reported the protein content of khichadi was $6.73 \%$. The findings of the present study are in line for crude protein content of khichadi reported earlier by Rahangadale et al., (2014) and Sethi (2003). The data revealed that the crude protein content of control biryani was 13.58 $\mathrm{g} / 100 \mathrm{~g}$. The crude protein content of HKR-48 biryani was $15.83 \mathrm{~g} / 100 \mathrm{~g}$. A significant difference was observed in crude protein content of both biryani.

\section{Crude fat}

A non-significant difference in fat content was observed between various food products prepared from control and HKR-48 rice varieties. A non-significant difference was observed in the crude fat content of both control and HKR-48 dosa. The results obtained for dosa investigation are lesser than range reported earlier by krishnamoorthy et al., (2013) and Beniwal and Jood (2015). The findings of the utthapam are agreement with results reported earlier by Ray and Swain (2013). The findings of the present study are more or less close to results reported earlier by Rahangadale et al., (2014) and Joshi and Srivastava (2016).

\section{Ash}

Similarly, A non-significant difference in ash content was observed between dosa, idli, utthapam and rice biryani prepared from control and HKR-48 rice varieties while HKR-48 khichadi (5.12g/100g) had significantly $(\mathrm{P}<0.01)$ lower ash content compared to control khichadi $(6.04 \mathrm{~g} / 100 \mathrm{~g})$. The findings of the present study are comparable with those reported earlier in dosa and utthapam by Amreen (2008), Asha et al., (2005) and Beniwal and Jood (2015).

\section{Crude fibre}

The crude fibre content of HKR-48 idli (0.48 $\mathrm{g} / 100 \mathrm{~g})$ and HKR-48 biryani (1.86 g/100g) was significantly $(\mathrm{P}<0.01)$ higher as compared to their control. A non-significant difference in crude fibre content was observed between dosa and khichadi prepared from control and HKR- 48 rice varieties, whereas HKR-48 utthapam (0.57 g/100g) had significantly $(\mathrm{P}<0.05)$ higher crude fibre content compared to control utthapam $(0.45$ $\mathrm{g} / 100 \mathrm{~g})$. The crude fibre content of HKR-48 biryani (15.83 g/100g), utthapam (4.49 
$\mathrm{g} / 100 \mathrm{~g})$ and khichadi (6.29 g/100g) had significantly higher values compared to their control. The findings of the present study are in line with those reported earlier in Dosa and Utthapam by Amreen (2008) and Beniwal and Jood (2015). The findings of the present study are in line with those reported earlier for crude fibre content in idli by Deshmukh and Pawar (2016) and Kumari et al., (2016). The findings of kichadi was more or less close to results reported earlier by Rahangadale et al., (2014), Joshi and Srivastava (2016) and Sethi (2003). The findings of the present study for proximate composition of biryani was found to be higher as compared to results reported earlier by Verma et al., (2015) and Umachandran et al., (2018).

Nutritional composition of rice varieties revealed that this product contains good amount of protein. All the food products from HKR-48 rice variety were organoleptically acceptable as compared to other varieties. In addition, results suggest that by selecting specific varieties of rice it would be possible to improve the performance of rice to prepare traditional food products, and presumably sensory evaluation could also be a good tool to obtain new promising varieties for traditional food preparation.

\section{Acknowledgment}

The authors are gratefully acknowledge the Rice Research Station, Kaul (District Kaithal), CCS Haryana Agricultural University, Hisar for contribution in the identification and procurement of newly released rice varieties used in this study. We would also thank the faculty members and students of department of Foods and Nutrition and Chaudhary Charan Singh Haryana Agricultural University, Hisar, Haryana, India, in guiding and supporting us in completion of the documented study.

\section{References}

Ambreen, A., 2008. Effect of oat based breakfast products on glycaemic response in NIDDM subjects. M.sc thesis. Department of foods and nutrition, Post Graduate and Research Centre, College of Home Science, Acharya N.G. Ranga Agricultural University, Rajendranagar, Hyderabad500030.

AOAC, 2000. Official methods of Analysis, Association of Official Analytical Chemist. Washington, D.C.

Asha, V.B., Geetha, K., Sheela, K. and Dhanapal, G.N., 2005. Nutritional composition of sorghum and moth bean incorporated traditional recipes. $\mathrm{J}$. Human Ecol. 17(3): 201-203.

Beniwal, P. and Jood, S., 2015. Development, chemical composition and Antioxidantn activity of dosa prepared using Bengal gram seed coat. International journal of advanced nutritional and health sciences. 3: 109-115.

Blandino, A., Al-Aseeri, M.E., Pandiella, S.S., Cantero, D. and Webb, C., 2003. Cereal-based fermented foods and beverages. Food Res Int. 36(6): 527543.

Coda, R., Rizzello, C.G., Trani, A. and Gobbetti, M., 2011. Manufacture and characterization of functional emmer beverages fermented by selected lactic acid bacteria. Food Microbiol. 28: 526536.

Deshmukh, G.P. and Pawar, P.P., 2016. Optimization of formulation and development of carrot fortified Idli and its physic-chemical characterization. International Journal of engineering science and research technology. 5(8): 783-786

Hotz, C. and Gibson R.S., 2007. Traditional food-processing and preparation practices to enhance the bioavailability 
of micronutrients in plant-based diets. J.Nutr. 137(4): 1097-100.

Joshi, S. and Srivastava, S., 2016. Barnyard Millet as a Substitute of Rice in Preparation of khichadi for Diabetics. International Journal of Science and Research. 5: 1798-1802.

Krishnamoorthy, S., Kunjithapatham, S. and Manicham, L., 2013. Traditional Indian breakfast (Idli and Dosa) with enhanced nutritional content using millets. Nutrition and Dietetics. 70(3).

Kumari, A., Prajapati, J., Angmo, K. and Taweechotipatr, M., 2016. Traditional fermented foods. Composition and nutritive value. Indigenous fermented foods of southeast Asia. Editors Taylor and Francis group. LIC. p 227-257

Moktan, B., Roy, a. and Sarkar, P.K., 2011. Antioxidant activities of cereal-legume mixed batters as influenced by process parameters during preparation of dhokla and $i d l i$, traditional steamed pancakes. Int J Food Sci Nutr. 62: 360-369.

Panse, Y.G. and Sukhatme, P.U., 1961. Statistical methods of agricultural workers. 2nd Edn. Indian Council of Agricultural Research, New Delhi. pp. 12-87.

Rahangadale, H.K., Khan, M.A., Rana, G.K. and Dubey, A.D., 2014. Process
Standardization and Quality Evaluation of Millets Fortified Khichdi for Diabetic patient. Department of Food Technology, College of Agriculture, J.N.K.V.V., Jabalpur (M.P.)

Ray, R.C. and Swain, M.R., 2013. Indigenous fermented foods and beverages of Odisha, India: An overview. In: Joshi, V.K. editor. Indigenous fermented foods of South Asia. USA: CRC Press.

Sethi, S., 2003. Development and nutritional evaluation of geriatric convenience foods. Ph.D Thesis. CCS HAU, Hisar.

Teniola, O.D. and Odunfa, S.A. 2001. The effects of processing methods on the level of lysine and methionine and the general acceptability of ogi processed using starter cultures. Int. J. Food Microbiol. 63: 1-9.

Umachandran, K., Sawicka, B., Nair, N.A.N. and Pasqualone, A., 2018. Nutritional features of biryani as the basis for the formation of an entrepreneurial mode in biryani market. Journal of Advances in Agriculture. 8(1): 1268-1278.

Verma, S. Srivastava, S and Tiwar, N., 2015. Comparative study on nutritional and sensory quality of barnyard and foxtail millet food products with traditional rice products. J Food Sci Technol. 52(8): 5147-5155.

\section{How to cite this article:}

Lavanya A. and Boora Pinky. 2019. Sensory Evaluation and Proximate Composition of Rice Based Traditional Food Products of India. Int.J.Curr.Microbiol.App.Sci. 8(06): 2008-2019. doi: https://doi.org/10.20546/ijcmas.2019.806.239 